\section{Little Hans, clever Hans and big Hans}

\section{Steve Blinkhorn}

Rebel with a Cause: An Autobiography. By Hans Eysenck. Allen: 1990. Pp. 310. £14.95.

As AN antidote to falling ratings, I propose the following plot for a television mini-series: handsome son of glamorous film star and excellent tennis player - no mean boxer - abandons promising career as physicist. Despite father's influence with Goering, flees Nazi Germany for England, escaping arrest by the SS and the concentration camps by seconds. Returns to Germany to smuggle out family jewels under nose of Gestapo. By chance, enrolls to study psychology; marries; completes $\mathrm{PhD}$ in wartime Britain, financed by wife.

War work in emergency psychiatric hospital; develops interest in hypnosis as a blind for introducing a bed into research rooms - real purpose, seduction of nurses. Cures case of impotence with gift of copy of Fanny Hill.

Professional advancement leads to establishment of own research department; political ideals bring many left-wing friends. Falls in love with glamorous daughter of famous musician; deserts wife and son to set up house with and later marry her, and lives happily ever after.

Writes popular books to supplement low academic salary, while inventing clinical psychology, behaviour therapy, personality theory and so on, at the same time dealing devastating intellectual blows to psychoanalysis, psychotherapy and all manner of pseudo-scientific superstition. All this while working only seven hours per day, two spent playing tennis.

Increasing fame leads to controversial stands on inheritance, race, intelligence, smoking, extra-sensory perception, astrology. Meanwhile, research department flourishes, standing in citation index grows, award of DSc.

The years pass; hair turns grey, but age cannot mellow him. Retirement brings yet more controversy, more books, more mould-breaking theories. Series ends as hero strides onto tennis court, still tall, still handsome, but now grave and distinguished; memories dance before his eyes, of battles fought and won, of students going on to found their own departments, and of the first girlfriend, back home in Germany, the Hitlermädchen he had to leave behind.

This is the story of Hans Eysenck,

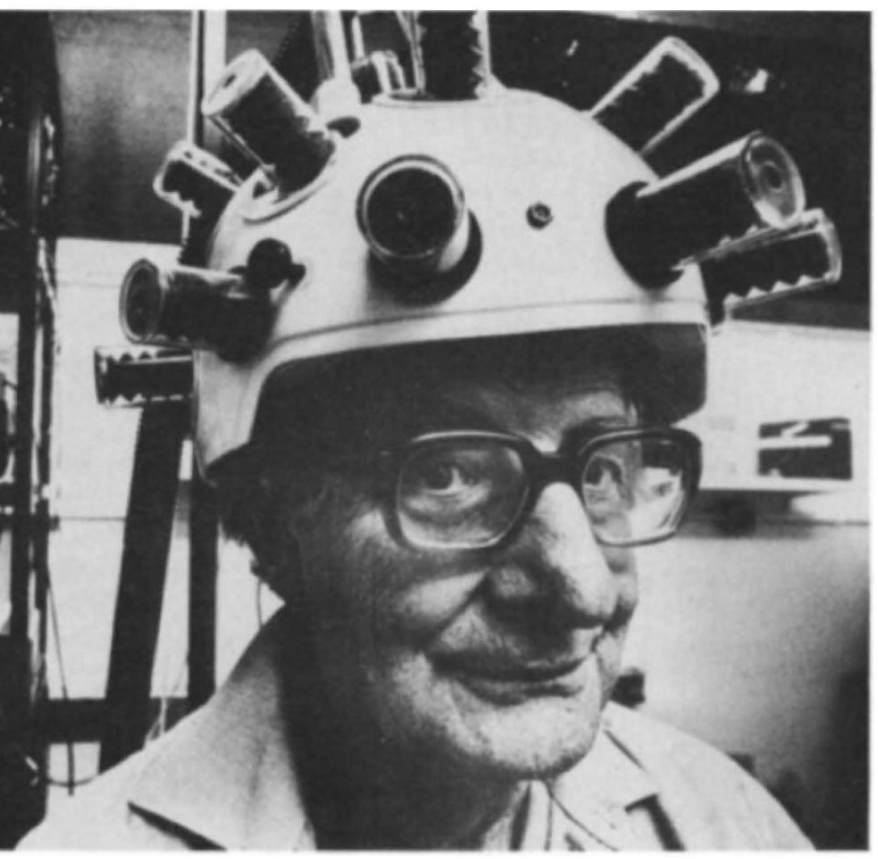

with just a hint of the outrageous and ridiculous".

A frequent reason for paying heed to the biography or autobiography of members of the intelligentsia is the expectation that their life histories will illuminate the development of their thinking. Psychologists may possibly be necessary exceptions to this principle. Certainly, Eysenck's line of attack is more to indicate how the theories he has developed or advanced shed light on the course of his life, which is a less than engrossing approach given the cool acceptance of the dictates of extramental forces that his approach to the psychology of learning and personality seems to indicate.

Throughout, there is a sense that events occur in obedience to the joint dictates of necessity and chance, in which motives, goals, values and desires, if they have a place at all, are little stressed and less regarded. Which, in terms of the proposed mini-series, leaves this reader a little bemused. The story is all plot mechanics and no character development, like a cross between The Thirty-Nine Steps and National Lampoon. The man is not central: his scientific pursuits are. Certainly those with any degree of personal acquaintance with our hero will readily recognize the self-portrait (and perhaps others will find it surprising: here is a man simplified a little, dramatized a touch, but embroidered not at all, as he tells it. Of course the emphasis is a little different, but insofar as there is a

personal story to tell, this is it.

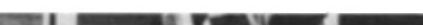
insecure position of an enemy alien in
wartime England, as elements in a dyna-
mic with great explanatory readers might well look to the suggestion of lack of parental attention in childhood, the break with roots in Germany, the personal style).

But the question does arise as to whether the self-portrait is any less a misreading of character than the media caricature of a superannuated enfant terrible - a caricature echoed in the book's title. Psychoanalytically inclined

power. But if there is an element which does seem understressed in Eysenck's account of his progress through life, it is the advantage of an outsider sufficiently at home in his adopted culture to operate effectively without the baggage of oversensitivity to subtle cultural controls.

There can scarcely be a scientist who has managed simultaneously to develop a successful department, become an effective popularizer of his subject and be the centre of popular controversy (with just a hint of the outrageous and ridiculous) to the extent that Eysenck has. His penchant for pressing an argument just one inference too far is simultaneously headline-grabbing and irritating. I wonder too whether all concerned will feel happy with his attributions of priority in the various fields of theory and research with which he has been concerned. As he himself puts it, British psychology in the 1940 s was essentially feudal. The resonances of disputes now 30 years old or more can still be detected by those with ears well tuned to ancient echoes. Yet one never has the sense that here is a vain man, even when there are touches of vainglory in his intellectual campaigns.

But this is meant to be a book review, not a character analysis. And so it must be said that autobiography is not Eysenck's natural métier. Perhaps because it is the least intellectually pugilistic, least controversial and tendentious, and most narrative of his works, it is less than gripping stuff. As a matter of record, it would have been a pity had it been left unwritten. But as an idiographic account of one man's life, which it explicitly sets out to be, it is disappointing. What is more, "idiographic" is misspelt virtually throughout. A slip that might have interested Professor Freud?

Steve Blinkhorn is Managing Director of Psychometric Research \& Development Ltd, Brewmaster House, The Maltings, St Albans AL1 3HT, UK. 